\title{
“着”の文法的意味
}

\author{
村 松 恵子 \\ (名古是大学大学院)
}

\begin{abstract}
至今, 将后续于动词和形容词之后的 “着” 是做为 “体态词 (体貌词)”进行 处置的。但对这个词的解释，各个研究人员各有其不同的解释。比如，既有把 “着” 这个词只做为后续动词之后的词进行分析的, 也有把 “着” 分别划分为后续动词和 后续形容词之后来进行论述的。

如木村英树是把后续在动词之后的 “着” 区别为 “进行貌”和 “持续貌”做了 分别处置。而荒川清秀则把后续在动词之后的 “着” 根据相结合的动词类型的差异, 做为分析的俵据。

本论文的着眼点, 首先是论述了木村与荒川对 “着”这个词在论证上所存在的 不足, 其次是把后续在动词之后的和后续在形容词之后的含有共性的 “着”, 从语 法的角度上总括地做了试探性的论述。
\end{abstract}

\section{1. 従来のとらえ方}

2. 「進行」の “着”と「持続」の“着”

\section{1. 従来のとらえ方}

従来, 動詞や形容詞に後置する附属形式の “着”はアスベクト辞として扱われてきた。 そしてその文法的意味は，“进行貌（王力 1943)"，“方亭相（吕权湘 1944）”，“进行体 （高名凯1948，王松茂 1981，俞敏 1983）", “持续貌 (汉语教科书)”, “进行态（趙元任 1968)”などと記述されてきている。しかし その記述を詳細に見ていくと，動詞に後娄す る “着”だけを分析の対象としているものむ あれば、動詞に後圈する “着”と形容詞に後 置する “着”を区别し, 動詞に後酎する “着” は「動作が正焳行していることを表わす」 とか,「動作の（結果の）持続を表わす」な どと述べ，形容詞に後圆する “着” は「状態 の持繶を表わす」などと記述されている。 その他，木村1981 -1986は，統浯論的特徵 の違いを論䞗として動詞に後圈する “着”を

\section{3. “着”と動詞}

4. “着” の文法的意味

「進行」の“着”と「持繶」の“着”に分け，

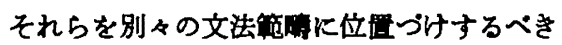
であると述べている。また荒川1985は，動詞 の類と “着”の結合度といら覞点から木村 1981に反駁している。

本稿で性，第 2 章炕いて木村 $1981 \cdot 1986$ を娭討し，そこで述べられている論拠が動詞 に後置する “着”を二つに分ける根拠として は不十分であることを諭証する。さらに第 3 章炕乱いて荒川1985を娭討し, “着” の文法 的意味を考察する場合, 動作動詞の語象的意 味の分析だけでは不十分であることを諭証す る。そして第 4 章において，本稿での“着” の文法的意味の分析を試みる。

なお，本文中の例文の成立，不成立の判定 Кついて、インフォーマントとして下記の 4 名の中国語のネイティブスピーカーに御協 カいただいた。 
绚绪忠: 大莗生れ，大連育ち，56藏

黄满海: 北京生れ, 北京育ち，大学卒莱後 大重, 44藏

铁 军：海陽生れ，小学校まで旅順，それ 以後北京, 34㰮

侯小南: 北京生れ, 北京育ち，24藏

2.「進行」の“着”と「持続」の“着” 木村1981は “着”を，功作が進行中である ことを表わす進行相の “着”” と, 動作が実 現した後の結果としての状留が持綍している ことを表わす持綂相の “着 $\mathrm{d}^{\prime}$ とに分け，各 々別個の機能籍原に屈すると考えるべきた， と論述している。そしてその根拠として “着p”と“着d”の統語詥的特徵の倳いを举 げている。下記の(1)〜(4)がそれである（例文 中の下線は等者)。

(1) “着d” は否定詞 “没（有）”共起可能 だが、“着っ”は不可能である。

(a) 桌子上没摆着d 碗。

(b) * 外头没下着 $\mathrm{p}$ 雨。

(2) “着”" は一般に連体格飾節内に極的て 生起しにくいが、“着d”㤌可能である。

(c) 他向桌上摆着d 的碄碗看了一眼。

(d) *他看着p 的书是水许。

(3) “着d”は副詞 “已经”と共起可能だが， “着p” は不可能である。

(e) 我起来的时侯, 他已经穿着d 大衣。

(f) * 我起来的时候, 他已经着着p 报纸。

(4)“着 $\mathrm{p}$ ” は副詞“在”之共起可能だが, “着d”は不可能である。

(g) *他在留着d 胡子。

(h) 他在刮着p 胡子。

そしてさらに木村1986において，“着" そ

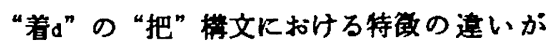
述べられている。下記の(5)がれである。

(5)“把”粠文において, “着い” は用いるこ とができるが，“着”は用いることができ ない。

(i) 焎饭给你留着d 呢。 （j）＊他把书看着p。

以下,この(1) (5)について順に検䖞を加え ていく。

2.1. “没（有）”との共起肉係について 木村1981は “着” は “没（有）之共起し ないとし（b)を不成立文としている。そこで 下記の例 1 の(A)と(B)を見てみよう。

例 1. (A) 甲：外面下著雨吗?

乙: 没有。/没下。/*没下曾。

(B) 甲：外面下着雨呢，你金去吧。 乙：外面没下盖雨，带伞干箭?

確か下, 例 1 (A)の甲の発話「外は雨か降っ ていますか。」に対して「いい光。と答える 場合，例1(A)の乙の上5に“没有。”あるい 㤌“没下。”答之, 通常“没下着。”之は答 えない。しかし例1(B)のよ5に，甲の「外は 雨が降っているから金をもっていきなさい よ。」といら発話に対して, 乙から「外は雨か 降っているなどといらことはないのに，全を もっていってどうするの。といらよらな答 え方をする場合，“外面没下着雨”といら文 は成立する。つまり“没下”之発話する場合 と“没下着”と発話する場合とでは，話し手 の, 事象に対するとらえ方が異なっている。 話し手は“没下”と発話する場合，「雨か降 るといら事象は起こらなかった」といらとら え方をしており，“没下着”と発話する場合 Кは、「雨が降るといら事象が起こってそれ が一定時間綂いている，といら事実はない」 といらとらえ方をしている。だから例 1 (A)の 甲の問いに対しては“没下”と答えれば十分 でありまた(B)の甲の問いに対してば没下 着雨”と答えても不自然ではない。

2.2. 連体修飾節内での生起について

木村1981は，“着d” は連体飾節内で生起 可能だが “着p”は極めて生起しにくいと速 へている。そこで下記の例 2 の(A)と(B)を比校 してみる。

例 2. (A) 他现在看的那本书是昨天我借给他 的。 
（B）他现在看着的那本书是昨天我借给 他的。

例 2 の(A)と(B)はどららす成立する。では(A) と(B)はどら速うのか。これる例 1 と同棣、話 し手の束象に対するとらえ方の䢖いが表現さ れている。詳述すれば，(A)は話し手が彼が 今あの本を読む」といら事象の実現を「今」 の一点でとらえた表現である。これに対して (B)は，話し手が「彼が今あの本を院む」とい ら亭象の实現を「今」を含むある一定の愊を もった時間でとらえた表現である。

また，木村の茟5 “着p”が連体签飾節内 で生起している例は小説やシナリオの中にる 多く見られ (下記の例 3 例 7 照)，稀な 表現形式とは言えない。

例 3. 而产卫人员只是㖪：“快点！快眼上!” 对笑落的人, ……(男 P. 30)

例 4. 为了摬水, 她上身有力地一起一伏, 宛 如一只㧹戏着的海原, （男 P.41）

例 5. 沉甸甸的麦䄼在微风中整齐地插来晃去, 象一群联咏着的女人, (男 P. 134)

例 6. 它一下子那么惊说, 左右都是一片素, 后面是疾驶着的，紧紧追赶着它的可怖的 怪物一汽车。(蝴P.101)

例 7. 正象天天青见我们而不理会我们身上流 着的是青春的血液（（金 P.156）

2.3. 副詞 “已经” との共起闺係について 副詞 “已经”との共起㒺係についても木村 1981は, “着d”は共起可能たが “着p”は不 可能たと述べている。これについては下記の
例 8 の(A)と(B)を比校してみる。

例 8. 他什么时候起的床我不知道, 但是我起 来的时候, $\{$ (A) 他五经臮报纸了。

(B) 他已经程着报纸了。

例 8 において(A)と(B)はどららる成立する。(A) は，話し手が「私が起きた時，すで彼が新 间を読むといら事象が起っていた」ととらえ た场合発話である。これに対して(B)は，話し 手が「私が起きた時，すで彼が新间を読み はじめて一定時間経過している」ととらえた 场合の発話である。つまり(A)は，「彼が新间 を讜む」といら事象の実現を「私が起きた」 その時点, その一時点でとらえた表現である のに対し，(B)は，「彼か新用を読む」という事 象の実現を「私が起きた」その時点を含む一 定の幅をるった時間でとらえた表現である。

2.1.〜2.3. で述べたことをまとめると，次 のよらに言らことができよう。

ある事象を認識し，それを言語化する際に， 話し手は必ずある時点を基準として言語表現 を行う。今，仮に，話し手が言語表現する際

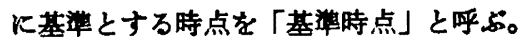

例 1 (A)乙と例 $2(A)$ ，例 8 (A)は，話し手が紊 象の央現を基整時点のまさにその一点でとら えた表現である。これに対し，例 1 (B)乙と例 2 (B)，例 8 (B)，さらに例 $3 〜$ 例 7 は，話し手 が素象の実現を基花時点を含むある一定の楅 をるった時間でとらえた表現である（図1参 照)。

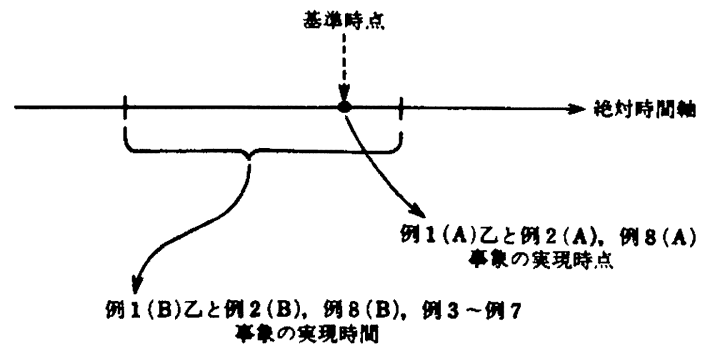

（四 1) 
木村1981が例 1 (B)乙中例 2 (B)，例 8 (B)を不 成立とするのは，基花時点において荚現した かしなかったかといらことだけに焦点をあて たからにはかならない。

2.4. 副詞 “在” との共起闺係について 次に副詞 “在”との共起网係については, 木村1981は, “着p”が共起可能で“着d”は 不可能たと述へている。

先の(g)は木村1981が不成立文としている通 り成立しない。しかし下記の例 9 は成立す 万。

\section{例 9.甲：小李呢?}

\section{乙: 他病了, 在艄差。}

例 9 の“着”は，木村1981の詥に従えば(8) と同じ“着d”である。(g)は成立しないが例 9 は成立する。とすると、“在”を用いた文 の成立，不成立を决定する要因は，“着』”で あるが着”“であるかといらことではなく， 他の文法的制約によると考える万が妥当であ ろら。

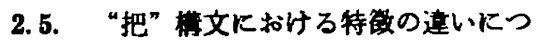
いて

さらに木村1986は，“把”構文における “着 $\mathrm{d}$ ” “着 $\mathrm{p} ”$ の特微の違いを举げ, “着 $\mathrm{d} ”$ は“把”桠文に用いることができるが, “着中” は用いることができないとしている。

先の(i)は木村1986が成立文としている通り である。しかし下記の例10，例11は成立しな い。

例10. * 今天他把红毛衣穿着。

例11. *今天他把腿镜盖着。

例10，例11の“着”は，木村によれば(i)と 同じ“着d”である。しかしこれらは成立し ない。また(j)は木村1986が不成立文としてい る通りである。が下記の例12は成立する。 例12. 他把鸡蛋故在锅里努着呢。

例12の“着”は，木村によれば(j)と同じ “着p”である。しかし例12は成立する。と すると，“把”權文の成立，不成立を決定す る要因が “着d”であるが“着p”であるかと
するのは, あゃしくなってくる。

以上の論述で明らかであるよ5に，木村 1981・1986は “着”の統語的機能を“着p” と “着d” の二つに分けているか，その諭拠 は、はなはだ弱いと言わざるを得ない。

\section{3. “着”之動詞}

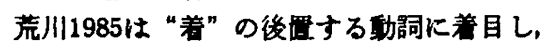
“着”と動詞の結合度とい5锶点から“着” を考察している。以下，荒川1985を検討しな

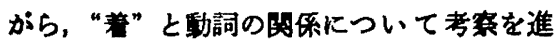
めていく。

荒川1985は動作動詞を 5 類に分けている (下記の a 類〜e 類)。そして『偊きの静か な、ある一定状留を保つような期詞』ほど 『“着”と自然に結びつく』とし，『“着”の 本質的な機能は「持繶」そのものである』と 这へてている。

（結合度）

〈高〉a 類：站，坐，躺，蹲，䟜/速2，摆2, 开2, 放2

b 類：芽2，金2，戴2，提2，端2，背2, 带2

c 類 : 歇, 待, 跟, 守, 活

d 類 : 等, 听, 雷 kān, 盯, 睡 (觉),

然, 陪, 萧 (病), (想)

〈低〉e 類：干，穿1，迋1

荒川1985は 5 類の類分けの基华の一つとし て,「 「 類〜 e 類の動詞+“着”」が命令文と して成立するかどらかといらことを誉げてい る。そして a 類〜d類の功詞は『それ自身動

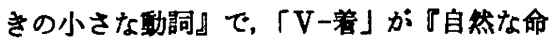
令文として成立する』か，e類は『干前，吃 着, 洗着, 说着，问着，买着』など不自然 なすのが多くなる』としている。しかし荒川 1985が不自然としているむのの中です“吃 着”ゃ“说着”などは，その行為を一定時間 ひき続さ行らことを命令する場面においては 成立可能な表現である。

例13. 你们吃着, 我一会再来。 
例14. 你们说着, 我去倒莱。

例13は，ある部屋に入ろらとしたらたまた まそこで何人かが食事をしているところだっ た，そこで「食事を綂けて下さい（綍けなさ い) あとでるら一度来ますから。」と発話す るよらな场合に成立する。

例14は，ある部屋で何人かが話しをしてい る際中に、「私」がみんなにお茶を入れよ5 と思って席を立ち，その時みんなが話しをそ こでやめてしまってはいけないと思って「話 しを緒けて下さい(繶けなさい)，私はお莱 を入れてくるから」と発話するよらな场合に 成立する。

これに対して “问着”中“买着”は，“问” 中 “买”といら動詞の示卞行為か一一定時間繶 けて行なわれるものとして諗識されないため 成立しない。

また荒川1985は分析の対象を動作動詞に限 っているか，“着” の後置する動詞は動作動 詞に限らない（下記の例15～例19参照)。 例15. 辽阔的田上迴荡着它们欢快的鸣叫。 (男 P. 28)

例16. 大自然充实得什么都不需要了, 而人却 渴望着爱情。(男P.28)

例17。逐斩消散的晨务中荡送着一片富有感染 力的笑声。(男 P. 30)

例18. 我用食指和中指去摩紫她的眼脸, 但想 不到这个已经变成一根枯朽的木柴棍的神 婆子，眼皮居然还保持着弹性。(男 P. 32) 例19. 正是在旅途中，时间的推移意味着空间 推移，…... (蝴P.126)

動作動詞以外の動呞の場合も, 例之ば “开 始”，“发现”，“知道”，“㑋”，“死”などのよ 5飞, 眼時にして䅂わり，一定時間繶く情況 として認識されないものは “着”と結合でき ない。

つまり動詞と“着”の結合度を覞る場合， その動詞の示す動きが大きいか小さいか，あ るいは静かであるか敬しいかといらことは， 大した問題ではない。重要なのは，その動詞
の示す仿況が一定時間続くものとして認驖さ れるかどらかといらことである。

そしてさらに，“着”が後榓するのは動詞 だけではなく、形容詞の特合もある゙（下記 の例20～例24照)。

例20. 外面还基着，你快回去吧。

例21. 土暖气还热着，不用烧了。

例22. 她的肚子还天差, 还没有生吧。

例23. 约一点也不灵, 头还还着。

例24. 慢着点儿。

よく「“着” は普通，動詞につく」と言わ れる。しかし “着”か形容詞に後置する场合 あある。また，中国語における動詞と形容詞 恃意味的にも梳語論的にも連繶性か高く, 両 者の境界線は引きずらい。従って, “着”の 文法的意味は堛詞たけけでなく形容詞に後滑す る “着”をる含めて考察されなければならな い。しかしこれですまだ不十分である。

下記の例25〜例27を見てみよう”。

例25. 路明遥从书包里掏出巴蓄舞辕，一面往 脚上穿着，一面对妈妈说。

例26. 她下边穿着条夹裤，上面空着件青布小 棉文，没系纽扣。

例27. 他们欺人太甚了。秦爷爷, 你不知道, 有些人真可恨，吃着我们包的饺子，穿着 我们织的毛衣，反过来又歧视我们，挤总 我们，我真受不了。(金P.160)

例25〜例27の “穿着”はそれぞれ異なった 倩況を表わしている。例25と例26の “穿着” が異なった倩況を表わし得ることについて荒 川1985は，“穿”といら動詞が語菒的に『変 化にいたる過程の局面（例25）』と『着テイ ル状態を䊒持する動作の局面 (例26)』の二 つの局面を表わす性格をもっているからであ るとしている。

確かに “穿” の類 (b 類) の語俚荒川1985 の言う通り，語事的に二つの局面を表わし得 ると言えるかる知れない。しかし例25と例 26 の “穿着”が表わす情況の逶いを決定するの は, 文中の “穿着” 以外の要萦である。詳述 
すれば，例25は “往脚上”とい5前置詞句と の共起，例26は “下边”，“上面”といら场所 を指定する名詞との共起によって，それぞれ の情況が決定されている。

また例2732は『第”といら動詞の変化に いたる過程の局面を描いている』のでもなけ れば，『着テイルといら状態を耯持する動作 の局面を描いている」のですない。この軥合 “穿着”は「私達が編んだセーターを着る」 といら行為が一回だけでなく，くり返し行わ れていることを意味している。同様に，この 文における “吃着”も，食べるといら動作そ のむのが進行しているとか持続しているとか いら意味ではなく、「私達が作ったギョーザ を食べる」といら行為が一回だけでなく、く ク返し行われていること意味している。

このように例25〜例27の“穿着”が表わす 倩況の違いは，動詞の語象的意味の分析だけ では説明できない。つまり「V-着」あるい は「Adj-着」がどのような情況を表わしてい るかを考察する場合は，動詞あるいは形容詞 の語集的意味を考えることは重要なことでは ある。がしかしそれだけでは不十分であり， それ以外の要素，例えば副詞や前疊詞句，名 詞句など文全体の推成要素，さらには話しの 場、文脈など一文を越えたレベルの要来も考 察しなければならない。その上で「一着」の 文の共通項を抽出し，その結果として “着” の文法的意味が明らかにされるのではないた 万らか。

以下このような镜点から“着”の文法的 意味を考察していく。

\section{4. “着” の文法的意味}

実あるいは虚世界の事象，現象，心象など は，話し手によって認識され，言語化される 際にある種の模型化が行われる。

この「模型化」の柢念について山田 1984 （P.45）は次のよ5に説明している。

、『模型化といら意味は，…...「せきをす
る」のをスローモーションで掫影すれば，ま ず辰がせきをする形に变り，のどの奥の状態 あ変り，のどから急做に息が音と共に吐き出 され，そのあと再びのども㕆の形む前の状態 にもどるという順序が明らかにされるはずた が，感覚的にはこれは一瞬のできごとで単一 の娌作と理解されるといらようなことを意味 する。』

本稿においても「棋型化」をこのよらな意 味で用いる。そして模型化された事象，現象， 心象などをここでは「出来事」と呼ふ。。

では，実あるいは虚世界の京象、現象，心 象などをどのような出来京としてとらえた時 に，話し手は“着”を用いるのか。これにつ いて次の二つの側面から考えてみる。

（1）時間的特性

（2）質的特性

\section{1. 時間的特性}

従来，“着”を論ずる場合，「持続」とか 「進行」といった説明が用いられてきた。 「持繶」「進行」のむつ意味のらち，時間的 な特性について言えば，どららむ瞬時にして 終わる出来事ではなく，ある一定の時間的幅 をもった出来事を意味する。本稿においても 「-着」の文は, 話し手が，実あるいは虚世 界の事象，現象，心象などを瞬時に終わるの ではなく，ある一定の時間的湢をもった出来 事としてとらえた表現であると考光る点にお。 いては基本的にかわらないが，この「ある一 定の時間的幅」といらことについては，む5 少し放密にみてみる必要がある。

下記の例28の(A)と(B)を比較してみる。 例28. (A) 我现在在名古室住。

(B) 我现在在名古屋住着。

例28の(A)と(B)はどちらも「私は今名古屋に 住んでいる」といら意味だが，例28(B)は“着” を用いることにより，それが一時的な出来事 であるという意味が付加され，「以前は别の ところに住んでおり，そしてまた別のところ へ移るかも知れないが，今は名古屋に住んで 


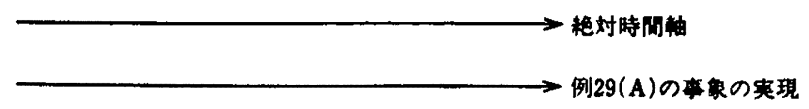

（图 2）

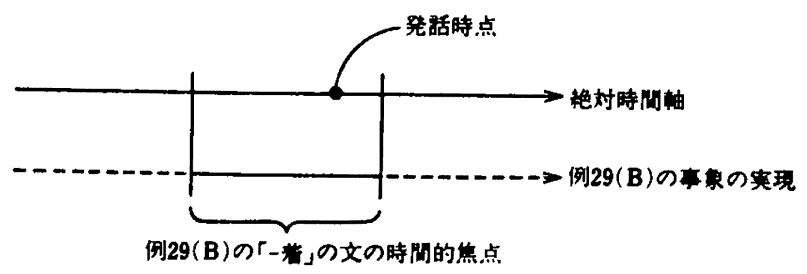

(因 3)

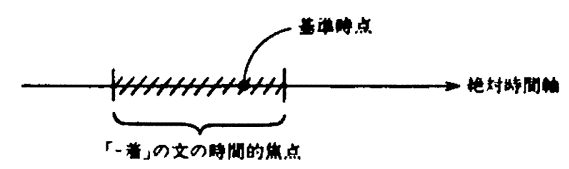

（因 4)

いる」といら意味になる。

さらに次の例29の(A)と(B)を比效してみる。

例29. (A) 地球围太阳转。

(B) 地球围着太阳转。

例29(A)は因2 亿示したよらに，絶対時間軸 と平行して実現している，いわは佰久的事実 の表現である。これに対して例29(B)は図 3 K 示したよらに，話し手が発話時点を含むある 一定の時間に焦点をあてて束象の実現をとら えた表現である。

つまり「一着」の文は图4 亿示したよ5に，

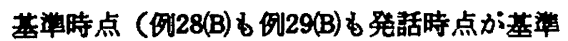
時点である）を含むある一定の幅をるった時 间に焦点をあてた表現である。

次に，“着”を用いることによって話し手 に焦点のあてられた時間内の算的特性につい て考察する。

\section{2. 質的特性}

例27をいまいちどみてみよら。

例27の “吃着我们包的饺子，穿着我们织的 毛衣”は第了章でも还べた通り，「私達が作 ったキョーザを食べる」という行為，そして
「私䞨が編んだセーターを着る」といら行為 か，一回だけでなくくり返し行われていると いらことを意味している。

実際にその行為が行われ，次化るら一度行 われるまでには時间的な間隔がある。しかる その間隔恃等间雨であるとは限らない。しか しそのくり返し行われる行為たけを取り上げ たとき，不均等な间隔は搭象され，全体とし ては連綄した線の概念でとらえられる。また くり返される行為自身, 毎回全く同じではな い。たとえば「ギョーザを食べる」といら行 為を考えてみてる，あるときは10個食べる （た）かる知れないし，またあるとさは15個 食べる（た）かも知れない。しかしそのよう な逶いは「一着」といら言語化の前ではすへ て抬象され，等質の行為のくり返しとして融 譩される (四 5 参照)。

また例25をとり上げても同漛のことが言え る。「ハレーシューズをはきながら母親と話 しをする」といら斋象を考えてみると，実際 には，自分が母親侸話しかける祭化をはく といら行為を中断したかる知れない。また， 


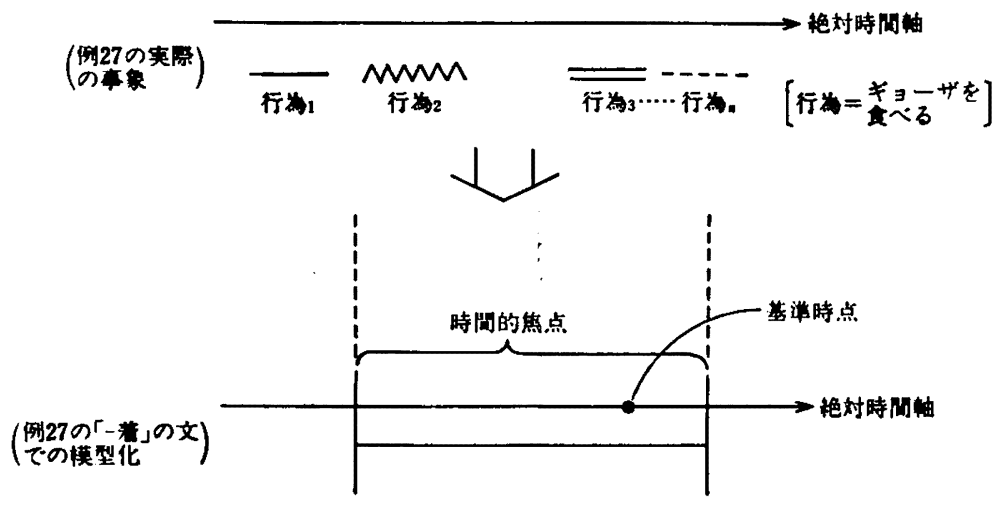

（因 5）
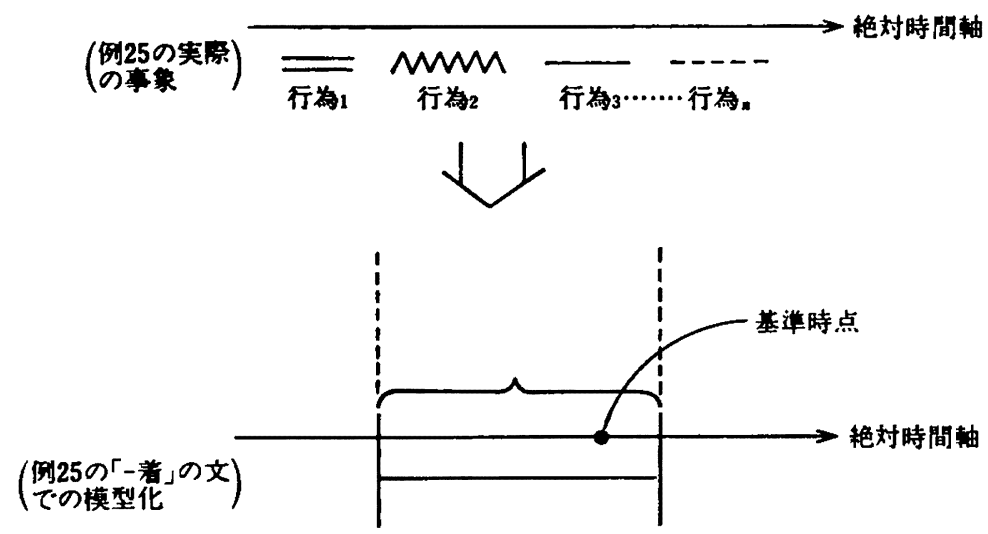

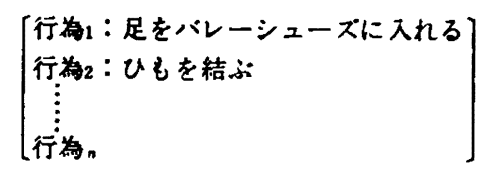

（図 6)

鞉をはくといら行為そのものを考えてみても。 夷際には足を靴を入れる行為やひるを結ぶ行 為など，さまざまな行為の総称であるとる言 える。しかし「着」といら言吾化の前にお いては, 靴をはくといら行為の中断は楇題と されずに連続した線の概念として認識され， 足を靴に入れる行為，ひるを結ぶなどの行為
の遗いは無視される。つまり, 話し手の焦点 があてられた時間内の出来亭は連続しており，

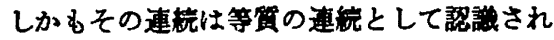
る(図6 照)。

さらに「Adj-着」の例として例22をみるこ とにする。

例22は，妊娠して大きなおなかをしている 


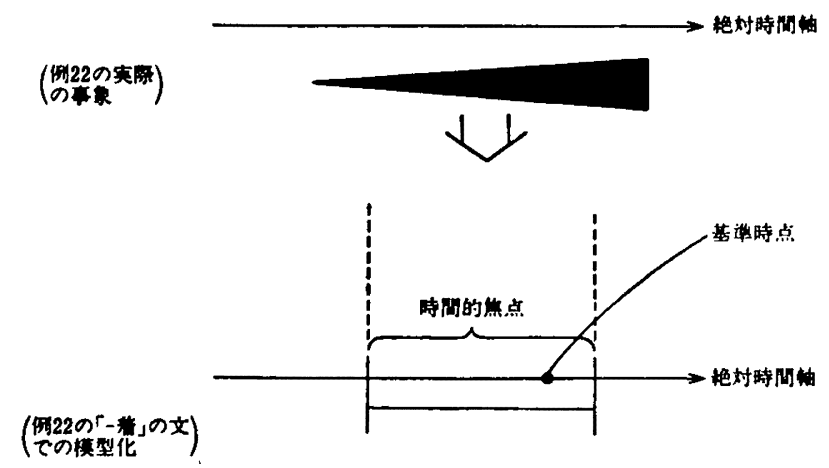

（図 7)

彼女を見て「彼女のおなかは依然として大き い」と認識している発話である。「妊娠した 人のおなかが大きい」といらことに時間的な 中断はない。が，その大きさは実際には時間 の経過とともに変化しているはずである。し かし「一着」といら言語化の前においては, これもやはり大きさの変化は搭象され，等筫 の連続として認識される(図 7 参照)。

以上述ぺてきたことは次のようにまとめろ ことができよう。

話し手は，実あるいは虚世界の事象，現象， 心象などを基整時点を含むある一定時間，等 貿的に連繶する（した）出来本として認識し た转合に「一着」の文を用いる。言い換えれ ば，“着”は話し手が，実あるいは虚世界の 本象，現象，心象を基汻時点を含むある一定 時間，等貿的に連繶する（した）出来事とし て認識していることを示す文法形式である。

\section{〈注〉}

1）「Adj-着」と「Adj-着呢」は、はっき りと区别する必要がある。

下記の(ガ〜(穴は“着呢”が一語として譏 能している例である。

(カ) 他的要求高着呢。

(1) 北京大着呢, 适三天都遜不完。

（六）他们俩人好着呢。
これらは “着呢”が常に一体となって機能 し,“着”たけでは成立しない。

(I) * 他的要求高着。

(才) * 北京大着, 适三天都逝不完。

(力) *他们俩好着。

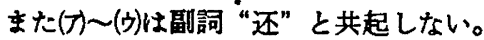

（†） *他的要求还高着呢。

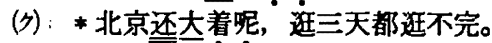

(名）*他们俩人还好着呢。

以上のことから，例20〜例24の “着”とけ 〜か)の“着呢”は全く別のむのとして报う べきであろら。

また「例24Kおける“着”は命令を表わ しているので，例文としては不迕当であ る」との意見があった。しかし，“着”が 命令といら文法的意味をになっているはず はない。ここで重要なのは, “慢着点儿!" といら表現と“憎点儿!”といら表現が発 話される際のニュアンスや鸤面の違いを考 察することである。

2）例25と例26は刘宁生1985に举げられてい た例文である。

例25：『张洁小说剧本选』 P. 194

例26：『老含〈路驼祥子〉』P.212

3）これはいわゆる “待业青年”の話しで, 自分たちを軽茂する人々に対する怒りを来 しいさんに遮べる埸面。「私道が作ったギ 
ョーザを食べたり，私達が編んだセーター を着たりしているくせに，また私達を軽蔍 して、はんとらにがまんできないわ」とい う発話。

\section{〈文献目辖〉}

王力1943. 『中国现代语法』。中华书局(1959)。 王力1944.『中国语法理论居。中华书局(1959)。 吕叔湘1944. 『中国文法要略的。商务印书馆 (1982)。

吕叔湘1979. 『现代汉语八百词』。商务印书 馆 (1980)。

高名凯1948. 『汉语语法论』。科学出版社 (1957)。

张志公1953. 「汉语语法常识」。上海教育出 版社，采華畫林 (1959)。

朱徳熙1981. 『语法讲义』。商务印书馆(1982)。 朱徳熙1980. P现代汉语语法研究』。商务印 书馆 (1985)。

『汉语知识』。人民教育出版社1957，采華表 林 (1959)。

『汉语教科书』。北京语言学院编 1958, 日本 語版『中国教科贯目光生館 (1960)。

䞻元任1968. PA GRAMMAR OF SPO-

KEN CHINESE』。 University of California Press。

丁声树1961. 『汉语语法讲话是。商务印书馆 (1979)。

『现代汉语虚词例释』。北京大学中文系1955 1957级语言班编，商务印书馆 (1982)。

俞敏1983. 『汉语知识讲话 名词动词形容 词』，上海教育出版社 (1984)。

孙徳宣1983. 『汉语知识讲话 助词和叹词』, 上海教育出版社 (1985)。
王松茂1981. 「汉语时态范畴论」、语言文字 学』第10期。

刘宁生1985. 「论 “着” 及其相关的两个动态 范梼」『语言研究』第 2 期。

寺村秀夫1982, 1984. 『日本語のシンタクス

と意味 I ・ II 。くろしお出版。 山田小枝1984.『マスペクト諭』。三答社。 平山久雄1959. 「北京語の「着」とその接尾 与る動詞について」、『中国語学88」。 木村英樹 1981.「「付着」の“着/2he/" と 「消失の “了/le/"」，『中国語』1981.7。 大館洁店。

木村英樹1986. 「“着”之“在”の否定」『中 国語』1986.11。大俗館害店。

荒川清秀1985. 「“着”と動詞の類」『中国 語』，1985.7。大落館害店。

森山卓郎1984. 「アスベクトの意味のきまり 方について」、日本語学』1984.12。明治 書院。

CHARLES N. LI/SANDRA A. THOMPSOM 1981. 『Mandarin Chinese』, University of California Press

例文引用作品，（）内略称

〈金子〉田份. 『话剧剧本选』, 中国社会科 学出版社1981。（金）

〈蝴蝶〉王蒙. 『王蒙集』海峡文艺出版社 1986。(蝴)

〈男人的一半是女人〉张贤亮。中国文联出版 公司1985。(男)

なお本桖は，1987年10月31日に日本大学に おいて開催された中国語学会第37回全国大会 で発表したものに，補正加筆したものであ る。 1988年 2 月20日 記 